\title{
Provision of leucocyte poor blood at the bedside
}

\author{
ELIZABETH MACNAMARA, SHEILA CLARKE, SR MC CANN \\ From the Department of Haematology, St James's Hospital, and Trinity College, Dublin, Ireland
}

SUMMARY The Imugard IG 500 cotton wool filter and the Cellselect cellulose acetate filter were adapted for filtration of leucocytes from packed cell transfusions at the bedside. Sixty five transfusions were given via the Imugard IG 500 filter and 54 transfusions were given via the Cellselect filter. Packed red cell concentrates from the National Blood Transfusion Service provided for routine blood transfusions were used in all cases. No patient in either group of multitransfused patients experienced a febrile blood transfusion reaction during the study. The Imugard IG 500 removed $91 \% \pm 9(\mathrm{SEM})$ leucocytes; the Cellselect removed $96 \% \pm 7$ (SEM) leucocytes. In the Imugard IG 500 group one patient received $>0.5 \times 10^{9}$ leucocytes, but no patient in the Cellselect group received $>0.5 \times 10^{9}$ leucocytes in any single transfusion. This is a safe method of providing leucocyte poor blood at the bedside.

Multiple blood transfusions may lead to the production of leucocyte antibodies, which in many cases are responsible for non-haemolytic febrile transfusion reactions.' The severity of these reactions depends on the number of leucocytes present in the transfused blood and the titre and type of antibody in the recipient, and they can be prevented or ameliorated by the transfusion of leucocyte poor blood. ${ }^{2}$ The transfusion of less than $0.5 \times 10^{9}$ leucocytes can prevent non-haemolytic febrile transfusion reactions in most sensitised patients. ${ }^{1}$ There are four methods of depleting blood of leucocytes: (a) separation of leucocytes and red cells by centrifugation followed by washing, using a blood cell separator or manual washing; (b) sedimentation of red cells by dextran and washing, followed by removal of the leucocyte rich fraction; (c) freezing and thawing of red cells using glycerol and liquid nitrogen; (d) filtration of blood where leucocytes are removed by selective trapping as the blood is passed through the filter. With centrifugation 65 to $88 \%$ of leucocytes can be removed, ${ }^{3}$ whereas with dextran sedimentation leucocyte depletion can be as high as $95 \% .^{4}$ Freezing of red cells in liquid nitrogen results in removal of more than $95 \%$ of leucocytes ${ }^{5}$ and the use of cotton wool and cellulose acetate filters results in removal of an average of $98 \%$ of leucocytes. ${ }^{6}$ Red cell loss during preparation of leucocyte free blood may vary from 12 to $42 \%$ after centrifugation, from 3 to $9 \%$ after dextran sedimentation, less than $10 \%$ after freezing, and averages $10 \%$ after filtration.?

Because of the large number of patients now

Accepted for publication 2 February 1984 receiving multiple transfusions in association with chemotherapy of haematological and other malignancies and for aplastic anaemia, it has recently been suggested that leucocyte depleted blood should be used in patients starting such multiple transfusion programmes whenever possible, to reduce the incidence and delay the onset of sensitisation among recipients. ${ }^{8}$ The purpose of our study was two fold. Firstly, to compare the efficiency of leucocyte removal using the Imugard IG 500 cotton wool filter and the Cellselect cellulose acetate filter and, secondly, to see if these filtration systems could be safely adapted for the use of packed cell transfusions at the bedside.

\section{Material and methods}

All patients receiving leucocyte poor blood were in the haematology unit. They were being treated for either acute leukaemia or severe aplastic anaemia.

Two filtration systems were evaluated. The Imugard IG 500 filter was compared with the Cellselect leucocyte filter, the former utilising cotton wool and the latter utilising cellulose acetate in the filter. Packed red cell concentrates obtained from the National Blood Transfusion Service for routine blood transfusion were used in all cases. The packed cells were diluted with $100 \mathrm{ml}$ of sterile normal saline in order to facilitate rapid transfusion. When using the Imugard filter, $200 \mathrm{ml}$ of sterile saline was initially passed through the filter into the waste bottle. The side tubing was subsequently sealed and the diluted red cell concentrate was attached and given directly through the filter in a blood giving set 669 


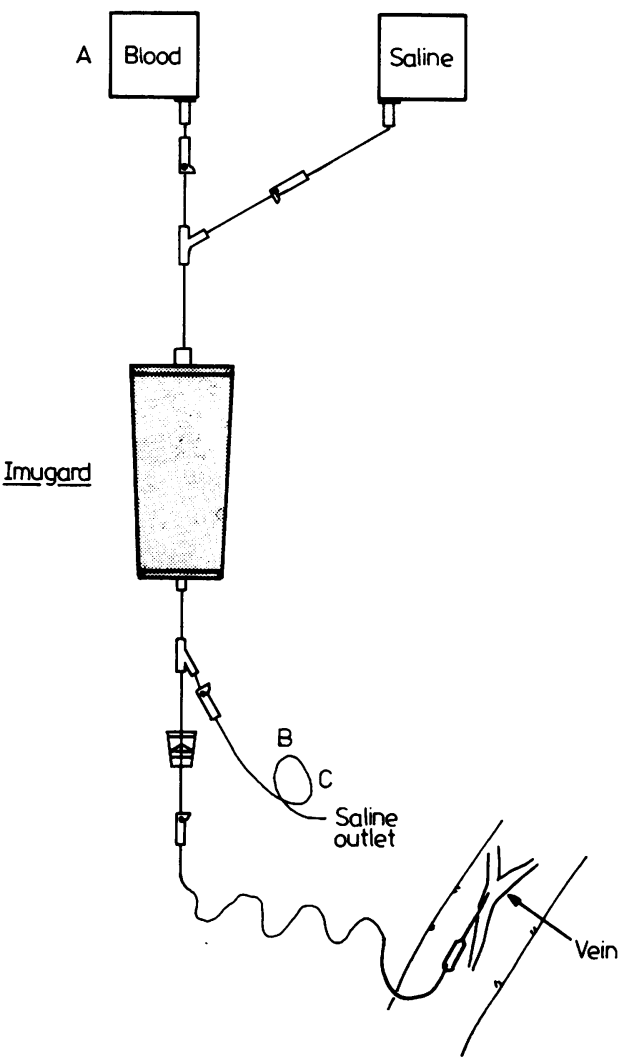

Fig. 1 Imugard filter with giving set attached. (A) Sample taken from red blood cell concentrate before transfusion. (B) Sample taken after transfusion and (C) after saline fush.

to the patient (Fig. 1). When the blood bag was emptied $200 \mathrm{ml}$ of saline was passed through the filter, flushing the remaining red cells into the patient. When using the Cellselect filter the filter was initially primed with $200 \mathrm{ml}$ of sterile saline using the vacuum as outlined in the diagram (Fig. 2). After transfusion of the packed cells, the filter was flushed with $200 \mathrm{ml}$ of normal saline, which was allowed to pass into the patient using a standard blood giving set.

A pilot study was carried out initially with the Imugard filter. Packed cell concentrates were transfused as described above using the Imugard IG $\mathbf{5 0 0}$ at the bedside. Altogether seven patients were studied. All patients were monitored throughout the transfusion, with temperatures measured every half hour and subsequently every $4 \mathrm{~h}$ for the next $24 \mathrm{~h}$. During the pilot study the post-transfusion saline flush was repeated up to five times to see if the leucocytes trapped in the filter could be inadvertently dislodged by accidental repeated flushing.

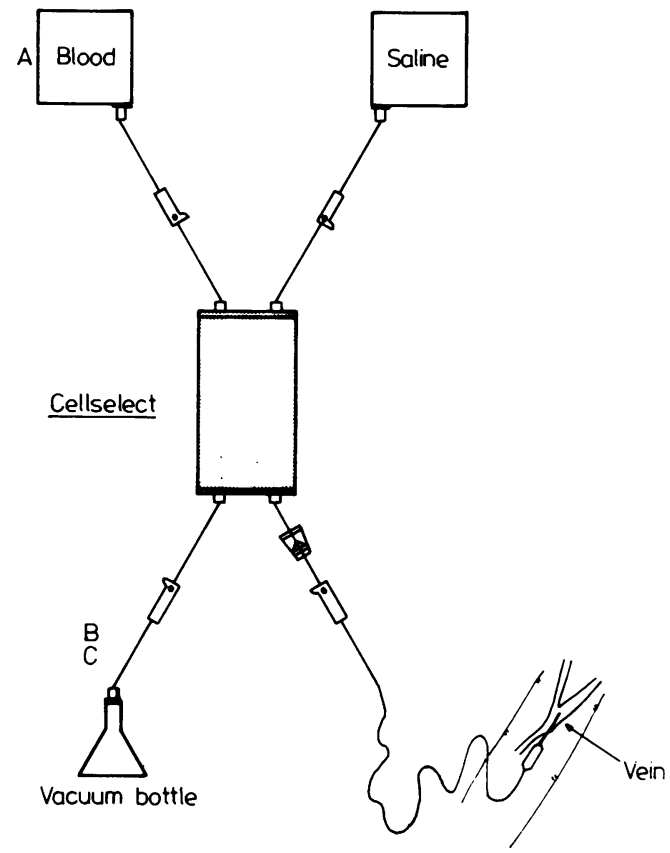

Fig. 2 Cellselect filter with giving set attached. (A) Sample taken from red blood cell concentrate before transfusion. (B) Sample taken after transfusion and (C) after saline fush.

After the pilot study 65 transfusions were given with the Imugard filter and 54 transfusions were given using the Cellselect filter.

\section{BLOOD SAMPLES}

Blood samples were taken for measurement of haemoglobin concentration and white cell count $(a)$ from the red cell pack before transfusion, $(b)$ from the infusion line distal to the filter after the red cell pack had been emptied, and (c) from the infusion line distal to the filter after a flush with $200 \mathrm{ml}$ of saline. During the pilot study multiple samples were taken from (c) after each flush through the filter.

Haemoglobin concentration and white cell count were measured on a Coulter $\mathrm{S}+$, calibrated with fresh human blood and $4 \mathrm{C}+$. Background counts were $0.0 \times 10^{9} / 1$ and each count was preceded by a wash. Random counts were checked on a Coulter ZF (background $0.05 \times 10^{\%} / \mathrm{l}$ ) calibrated against a manual counting technique. Calculations were carried out on a Hewlett Packard HP85 using a general statistics pack.

\section{Results}

IMUGARD

No patient became febrile, at the time of or after 
Table 1 Results of pilot study using Imugard

\begin{tabular}{|c|c|c|c|c|c|}
\hline \multirow{2}{*}{$\begin{array}{l}\text { Patient } \\
\text { JB }\end{array}$} & \multicolumn{2}{|c|}{$\begin{array}{l}\text { White cell count } \\
\left(\times 10^{9} / l\right)\end{array}$} & \multirow{2}{*}{$\begin{array}{l}\text { Patient } \\
\mathrm{MH}\end{array}$} & \multicolumn{2}{|c|}{$\begin{array}{l}\text { White cell count } \\
\left(\times 10^{\circ} / l\right)\end{array}$} \\
\hline & $\begin{array}{l}\text { Pre } \\
\text { Post } \\
\text { Flush }\end{array}$ & $\begin{array}{l}4 \cdot 5 \\
0 \cdot 1 \\
0 \cdot 05\end{array}$ & & $\begin{array}{l}\text { Pre } \\
\text { Post } \\
\text { Flush (1) }\end{array}$ & $\begin{array}{l}1.7 \\
0.3 \\
0.3 \\
0.15\end{array}$ \\
\hline \multirow[t]{3}{*}{ JB } & $\begin{array}{l}\text { Pre } \\
\text { Post } \\
\text { Flush (1) }\end{array}$ & $\begin{array}{l}2 \cdot 85 \\
0 \\
0\end{array}$ & & (3) & $\begin{array}{l}0 \\
0\end{array}$ \\
\hline & $\left.\begin{array}{l}(2) \\
3 \\
4 \\
5\end{array}\right)$ & $\begin{array}{l}0.05 \\
0.05 \\
0.05 \\
0.1\end{array}$ & JB & $\begin{array}{l}\text { Pre } \\
\text { Post } \\
\text { Flush }\end{array}$ & $\begin{array}{l}0 \cdot 45 \\
0 \\
0\end{array}$ \\
\hline & & & ED & Pre & $6 \cdot 6$ \\
\hline \multirow[t]{3}{*}{ JB } & $\begin{array}{l}\text { Pre } \\
\text { Post } \\
\text { Flush (1) }\end{array}$ & $\begin{array}{l}3 \cdot 4 \\
0 \\
0\end{array}$ & & $\begin{array}{l}\text { Post } \\
\text { Flush (1) }\end{array}$ & $\begin{array}{l}0 \cdot 1 \\
0 \\
0\end{array}$ \\
\hline & $\left(\begin{array}{l}2 \\
2\end{array}\right)$ & $\begin{array}{l}0 \\
0\end{array}$ & & & \\
\hline & (3) & 0.05 & TH & $\begin{array}{l}\text { Pre } \\
\text { Post }\end{array}$ & $\begin{array}{l}3.2 \\
0.15\end{array}$ \\
\hline \multirow[t]{3}{*}{ MH } & $\begin{array}{l}\text { Pre } \\
\text { Post }\end{array}$ & $\begin{array}{l}4 \cdot 8 \\
0 \cdot 4\end{array}$ & & Flush (1) & $\begin{array}{l}0.3 \\
0.2\end{array}$ \\
\hline & Flush (1) & $\begin{array}{l}0 \cdot 2 \\
0 \cdot 05 \\
0\end{array}$ & & (3) & $\begin{array}{l}0.15 \\
0.05\end{array}$ \\
\hline & (4) & 0 & JB & Pre & $\begin{array}{l}5.65 \\
0.0\end{array}$ \\
\hline \multirow[t]{2}{*}{ MH } & $\begin{array}{l}\text { Pre } \\
\text { Post }\end{array}$ & $\begin{array}{l}6 \cdot 5 \\
0 \cdot 1\end{array}$ & & Flush & 0.05 \\
\hline & Flush 1 & 0.05 & JB & $\begin{array}{l}\text { Pre } \\
\text { Post }\end{array}$ & $\begin{array}{l}1 \cdot 1 \\
0\end{array}$ \\
\hline \multirow[t]{2}{*}{ JB } & $\begin{array}{l}\text { Pre } \\
\text { Post } \\
\text { Flush (1) } \\
\end{array}$ & $\begin{array}{l}2.4 \\
0.1 \\
0.05 \\
0\end{array}$ & & $\begin{array}{r}\text { Flush (1) } \\
\text { (2) } \\
(3)\end{array}$ & $\begin{array}{l}0.2 \\
0.2 \\
0.05\end{array}$ \\
\hline & $\begin{array}{l}(3) \\
(4)\end{array}$ & $\begin{array}{l}0 \\
0 \\
0.05\end{array}$ & ED & $\begin{array}{l}\text { Pre } \\
\text { Post } \\
\text { Flush (1) } \\
\end{array}$ & $\begin{array}{l}7 \cdot 5 \\
1 \cdot 1 \\
0 \cdot 9 \\
0 \cdot 1\end{array}$ \\
\hline ED & $\begin{array}{l}\text { Pre } \\
\text { Post } \\
\text { Flush (1) } \\
\left.\qquad \begin{array}{l}1 \\
(3) \\
\\
\text { (4) }\end{array}\right)\end{array}$ & $\begin{array}{l}3 \cdot 85 \\
0.45 \\
0 \cdot 35 \\
0 \cdot 1 \\
0 \\
0\end{array}$ & & & \\
\hline
\end{tabular}

$0.0=<0.1 \times 10^{9} / 1$

transfusion during either the pilot study or the remainder of the study using the Imugard IG 500 filter. One patient became febrile $2 \mathrm{~h}$ after transfusion using the Cellselect filter. This patient had received a pseudomonas vaccine on the day of the transfusion. Subsequently, he was transfused using the Imugard filter and had no further febrile reac- tions. In the group receiving leucocyte poor blood via the Imugard filter two patients were known to have had severe febrile reactions to packed cell transfusions before the study. These patients were also refractory to random donor platelet transfusions. Neither of these patients had a febrile reaction during the study and both patients received multiple platelet transfusions from HLA matched sibling donors. Seven patients in this group also received multiple random six donor unit platelet transfusions during the study. All of these patients showed satisfactory incremental rises in platelets $1 \mathrm{~h}$ after platelet transfusion and none had a febrile episode either during platelet transfusion or during leucocyte poor blood transfusion, suggesting that appreciable concentrations of antibody did not develop in this highly transfused group of patients. ${ }^{9}$

\section{CELLSELECT}

In the group receiving leucocyte poor blood by the Cellselect filter, one patient had had a severe febrile reaction after red cell transfusion before the study. This patient was also refractory to random donor platelets. He received HLA matched platelets during the study and had an adequate platelet incremental rise. At no time did he become feverish.

Seven patients received multiple six unit random donor platelet transfusions during the study and all had adequate incremental rises in platelet counts $1 \mathrm{~h}$ after transfusion. No patient experienced a febrile episode during or after platelet transfusion.

The results of the pilot study are shown in Table 1 . A total of seven patients received 15 red cell transfusions. Red cells were flushed through repeatedly up to five times. The results indicate no appreciable increase in leucocytes being transfused following multiple saline flushes. After the first flush subsequent flushes were collected into a transfer bag to prevent fluid overload to the patient.

The number of patients receiving multiple transfusions and the number of transfusions given to each patient using both filter types are shown in Table 2 . The details of transfusions given by the Imugard and Cellselect filters are shown in Table 3. The mean

Table 2 Number of patients receiving multiple transfusians and number of transfusions given to each patient using both filter types

\begin{tabular}{|c|c|c|c|c|c|}
\hline \multicolumn{3}{|c|}{ Imugard IG500 } & \multicolumn{3}{|c|}{ Cellselect } \\
\hline $\begin{array}{l}\text { No of } \\
\text { Patients }\end{array}$ & $\begin{array}{l}\text { No of red blood cell } \\
\text { transfusions given to } \\
\text { each patient }\end{array}$ & $\begin{array}{l}\text { Total no of units } \\
\text { transfused }\end{array}$ & $\begin{array}{l}\text { No of } \\
\text { Patients }\end{array}$ & $\begin{array}{l}\text { No of red blood cell } \\
\text { transfusions given to } \\
\text { each patient }\end{array}$ & $\begin{array}{l}\text { Total no of units } \\
\text { transfused }\end{array}$ \\
\hline $\begin{array}{l}2 \\
6 \\
3 \\
3 \\
1 \\
1 \\
1\end{array}$ & $\begin{array}{r}1 \\
2 \\
4 \\
5 \\
6 \\
7 \\
11\end{array}$ & $\begin{array}{r}2 \\
12 \\
12 \\
15 \\
6 \\
7 \\
11\end{array}$ & $\begin{array}{l}4 \\
6 \\
2 \\
1 \\
3 \\
1 \\
1\end{array}$ & $\begin{array}{l}1 \\
2 \\
3 \\
4 \\
5 \\
6 \\
7\end{array}$ & $\begin{array}{r}4 \\
12 \\
6 \\
4 \\
15 \\
6 \\
7\end{array}$ \\
\hline
\end{tabular}


Table 3 Details of transfusions given by the Imugard and Cellselect filters

\begin{tabular}{lll}
\hline & $\begin{array}{l}\text { Imugard } \\
\text { (65 procedures) }\end{array}$ & $\begin{array}{l}\text { Cellselect } \\
\text { (54 procedures) }\end{array}$ \\
\hline $\begin{array}{l}\text { Mean white cell count } \\
\text { of red blood cell } \\
\text { concentrate }\left(\times 10^{\circ} / 1\right)\end{array}$ & $4.24 \pm 2.01$ (SD) & $6.77 \pm 3.83$ (SD) \\
$\begin{array}{l}\text { Mean white cell count } \\
\text { transfused per unit red } \\
\text { blood cells }\left(\times 10^{\circ} / 1\right)\end{array}$ & $* 0.12 \pm 0.14(\mathrm{SD})$ t0.14 \pm 0.11 (SD) \\
\hline
\end{tabular}

"One patient received $>0.5 \times 10^{\circ}$ white blood cell in this group. †No patient received $>0.5 \times 10^{9}$ white blood cell in this group.

percentage of leucocytes removed by the Imugard filter was $96 \% \pm 7 \%$ (SEM) and this fell to $91 \% \pm$ 9\% after saline flushing. For the Cellselect filter the mean percentage of leucocytes removed was $96 \% \pm$ $7 \%$, after transfusion and this was $96 \% \pm 5 \%$ after saline flushing. As can be seen from Table 3, the absolute number of leucocytes in each red blood cell pack was variable. Because of this large variation in leucocyte count and because it has been suggested that the transfusion of $<0.5 \times 10^{9}$ leucocytes can prevent non-haemolytic transfusion reactions the results were calculated in the following way. The absolute number of leucocytes was estimated in all red blood cell concentrates after dilution with saline - that is, before transfusion-and expressed as number of white blood cells $\times 10^{9}$. Similarly, the absolute number of leucocytes passing into the patient with the red blood cell concentrate (B) and after the saline flush (C) was expressed as white blood cell $\times 10^{9}$. The total number of leucocytes transfused into each patient was the sum of B and C, expressed as white blood cell $\times 10^{9}$. In the group receiving blood filtered using the Imugard IG 500, one patient received more than $0.5 \times 10^{9}$ white blood cells on one occasion (total $0.77 \times 10^{9}$ white blood cells) and in the Cellselect group no patient received more than $0.5 \times 10^{9}$ white blood cells in any single transfusion.

\section{Discussion}

If one accepts the desirability of preventing or delaying the onset of sensitisation, then the provision of leucocyte free blood becomes a reasonable prospect in patients embarking on a multiple transfusion programme. To date, the preparation of such products is undertaken by the transfusion service or the haematology laboratory. The centrifugation, sedimentation, or freezing of blood requires the use of sophisticated equipment and laboratory technician time. Filtration using specific leucocyte filtration depletion filters is a promising technique and is a most efficient way of removing leucocytes. To date, microaggregate filtration is the only technique that is at present applicable at the bedside.

The advantages of using filtration to provide leucocyte free blood at the bedside are obvious. Firstly, haematology laboratory technical staff are not needed and thereby the cost is reduced. Secondly, as we have shown, red cell concentrates which are issued by the transfusion service on a routine basis are adaptable to filtration. Thirdly, the procedure is simple and safe and can be carried out by nursing personnel. Finally, the inadvertent flushing of large amounts of saline through the filter does not result in the release of trapped leucocytes. Adapting the Imugard or Cellselect to the bedside therefore facilitates the rapid, simple and safe transfusion of leucocyte poor blood to patients undergoing multiple transfusions. The removal of leucocytes is satisfactory, and it can be expected that fewer than $1 \%$ of patients would receive more than $0.5 \times 10^{9}$ leucocytes. Further studies should be carried out to assess the incidence of sensitisation in patients receiving multiple transfusions of filtered blood at the bedside.

We wish to thank the National Blood Transfusion Service for their help during this study.

The Imugard filter can be obtained from Terumo Corporation, 881D30S-18 Tokyo, Japan, and the Cellselect filter from NPBI, Maasluisstraat 574, 1062 G2 Amsterdam, The Netherlands.

\section{References}

' Perkins HA, Payne R, Ferguson J, Wood M. Non-haemolytic febrile transfusion reactions. Quantitative effect of blood components with emphasis on isoantigenic incompatibility of leucocytes. Vox Sang 1966;11:578-600.

${ }^{2}$ Payne $\mathbf{R}$. The association of febrile transfusion reactions with leuco-agglutinins. Vox Sang 1957;2:233-41.

${ }^{3}$ Meryman HT, Bross J, Lebovitz R. The preparation of leucocyte-poor red blood cells. A compatative study. Transfu- $\bar{O}$ sion 1980;20:285-92.

${ }^{4}$ Cassel M, Phillips DR, Chaplin H. Transfusion of buffy-coat poor red cell suspensions prepared by dextran sedimentation: Description of newly-designed equipment and evaluation of its use. Tranfusion 1962;4:216-20.

s Amer KA, Pepper DS, Urbaniak SJ. Lymphocyte granulocyte and platelet contamination of blood frozen by the low glycerolo liquid nitrogen technique. Br J Haematol 1980;44:253-61. ․ㅡ․

- Sirchia G, Parravicini A, Rebulla P, Fattori L, Milani-S. Evalua- N tion of three procedures for the preparation of leucocyte poor-S and leucocyte-free red blood cells for transfusion. Vox Sang N 1980; 38: 197-204.

' Hughes ASB, Brozovic B. Leucocyte depleted blood: An appraisal of available techniques. $B r J$ Haematol 1982;50:381-6.

${ }^{8}$ Polesky HF. Leucocyte poor blood, a study on the evolution of component therapy. A seminar on blood components. $\mathscr{D}$ Atlanta, Georgia: American Association of Blood Banks, + 1977:53-74.

' Daly PA, Schiffer CA, Aisner J, Wiernik, PH. Platelet transfusiono therapy. JAMA 1980;243:435-8.

Requests for reprints to: Dr SR McCann, Department of $\frac{\rho}{\mathbb{Q}}$ Haematology, Central Pathology Laboratory, St James's $\varrho$ Hospital, James's Street, Dublin 8, Ireland. 